\title{
CÓMO DEBE SER LA OPCIÓN VOCACIONAL PARA LOS JÓVENES HOY EN LA IGLESIA
}

DOI: https://doi.org/10.52039/seminarios.v51i177.704

Autora: Maria Theresa Thiele. Fscj. Asesora de la Conferencia de Religiosos de Brasil.

Parte de la experiencia de dos encuentros con jóvenes vocacionados, en todos la seducción que ejerce el Señor les mueve a superar dificultades y dejarse conducir por él. El camino es el contacto con Jesús en el Evangelio que nos descubre la verdadera identidad.

\section{Introducción}

Mi punto de partida son dos encuentros con jóvenes vocacionados. El primero, con un joven de confesión luterana de Brasil, natural del Estado del Espírito Santo; el segundo con un grupo de jóvenes postulantes brasileñas provenientes de diferentes Estados.

Conocí al estudiante de teología durante el viaje de São Paulo a Porto Alegre, hace dos semanas. Me decía que desde niño los padres lo habían introducido en la vida de la Iglesia a que pertenecen. En la Escuela Dominical siempre se encontró bien; la misma alegría experimentó en el grupo de jóvenes y en la comunidad. Poco a poco se le fue convidando a colaborar y fue sintiendo que podría donar la vida por la vida de lo niños, de los jóvenes, de los enfermos y de los que están abandonados, especialmente. La idea fue madurando y ahora se dirigía al Sur para afrontar los 5 años necesarios de preparación al ministerio. Para esto está afrontado la 
distancia de la família y de los amigos y amigas. Hasta a su novia dejó para construir su historia sin ella. Todo fue muy duro, pero la llama interior fue mayor. Estoy decidido a aprovechar bien este tiempo de formación y ampliar los horizontes para transformarme en una persona capaz de comprender a las demás. Y concluyó, me siento fascinado por Dios, por Su causa, por la posibilidad de ser presencia significativa en la vida de las comunidades de la Iglesia de Confesión Luterana de Brasil, donde quiera que fuese enviado. Como ejemplo de fidelidad al proyecto de Dios asumido por una persona, citó Ir. Doroty Stang, recientemente asesinada en el Pará, por su alineamiento en la defensa de los derechos humanos.

Con las jóvenes postulantes en el RS, la amistad fue surgiendo y madurando a lo largo de los tres años en los que colaboré en el Instituto de Pastoral de Juventud, en Porto Alegre. Me decían ellas, especialmente en uno de los encuentros, ya casi al final de etapa: Nos fascinó la persona de Jesús de Nazaret y la causa por la que dio su vida. Por eso estamos aquí y continuamos hasta hoy nuestro camino. Entretanto, sentimos que la orientación que recibimos de nuestras formadoras y formadores apuntan, no pocas veces, para otra dirección. Tenemos la certeza de que buscan sinceramente lo mejor para nosotras. Muchas veces nos preguntamos no por el camino que estamos recorriendo sino sobre adónde vamos a llegar. Venimos de familias sencillas, trabajadoras, pobres, de fe profunda vivida en la rutina del día-a-día. Al llegar a la Congregación, pasamos a vivir en una casa de clase media. Tenemos todo, sin saber de donde viene. Aprendemos a conocer la moda, ropas de grife, calzados, perfumes, cosméticos que no formaban parte de nuestras costumbres. Cambiamos de clase social, del ambiente rural al urbano, de nuestra realidad a otra totalmente diferente. Experimentamos un fuerte y rápido cambio cultural. Y fuimos transformándonos en burguesas. Nuestros familiares nos ven con otros ojos. Parece que la pertenencia a ellas quedó debilitada. Nuestras necesidades habían aumentado en mucho. Nos estamos acostumbrando a una vida fácil. Todo nos es ofrecido enseguida: casa, tratamiento de salud, comida, estudio, pasajes... ¡Y Ya no somos las mismas! Sabemos que la Congregación invierte en nosotras, mas no nos sentimos protagonistas del proceso de nuestro camino. La oración pierde espontaneidad, se tornó difícil. Tenemos tiempo para el trabajo personal y para el propio cultivo, pero lo que hacemos en este tiempo parece no responder a lo que buscamos en lo profundo de nosotras mismas. ¿Cómo y qué rezar? ¿Cómo optar efectiva- 
mente por Jesús de Nazaret? ¿Cómo asumir Su causa? ¿Cómo vivir según Su estilo de vida? Las Hermanas hablan y presenta como modelos mucho más a los Fundadores de nuestras Congregaciones que a Jesús. Y nosotras sentimos que nuestro corazón palpita fuerte cuando Él se hace presente en nuestra vida con verdad y fuerza. En las/los religiosos/as de más edad encontramos, en general, una espiritualidad más cristocéntrica que da sentido a sus vidas. El amor que alimentan por Jesús los/las torna felices y, en la medida de lo posible, apostólicamente activas.

\section{Algunas reflexiones a partir de estas dos situaciones:}

La vocación cristiana tiene mucho que ver con el amor de una pareja. Hay un primer encuentro, seguido de muchos otros, pero lo diferencial está en la seducción recíproca. También la Persona de Jesús de Nazaret atrae, fascina, seduce. Es una seducción fuerte, irresistible. Dice el profeta: "¡Me sedujiste, Señor, y yo me dejé seducir!” Por causa de esta seducción, ganancias y honores se convierten en pérdidas. Todo se relativiza. Jesús pasa a ser el único que verdaderamente importa a la persona. Él se convierte en el Primero y el Último. Aquel que es, que viene y que de nuevo vivirá eternamente.

Nadie tiene vocación, en el sentido de algo ya terminado y recibido como un pago presente y ofrecido por otra persona. Algo medio mágico de lo que la persona no es protagonista y, mucho menos, responsable. La vocación cristiana es una responsabilidad asumida, por causa del amor al que conduce la seducción. Vocación cristiana es una historia de fascinación y de Amor. Es como un fuego que no se apaga. Como un sello gravado en el corazón... un rayo de Dios, al decir del autor del Cantar de los Cantares.

Un llamado está siempre hecho por alguien y dirigido a alguien. Por eso mismo es respuesta a ese ALGUIEN. Es resultado de una relación que se fue estableciendo poco a poco, con Alguien capaz de dar sentido a la propia existencia, para por encima de otras tantas seducciones, obstáculos y problemas con que la persona podrá llegar a tener que confrontarse y enfrentarse. Es llamado que viene de Alguien capaz de llenar de contenido y significado la donación de sí hasta el don total de la propia vida.

Nada ni nadie en este mundo, por más santo y perfecto que sea, podrá jamás ser colocado como fundamento de vida de una persona. El único 
fundamento es Jesucristo, el Hijo muy amado del Padre. Uno solo es vuestro Maestro y Señor.

La iniciativa es de Jesús. Todos y todas somos invitados/as por Él. Jesús es la Fuente de toda vocación cristiana. Más aún, todo 1lamado apunta a una misión. Nadie se da la misión a sí mismo/a. La misión nos es dada por otro, por el Otro, por Aquel que tomó la iniciativa de aproximársenos. Aproximar es hacerse próximo. Jesús se convierte así en el primero de todos los prójimos que alguien pueda encontrar a lo largo de su existencia. No es por casualidad que el evangelista registró la pregunta del doctor de la Ley sobre esta cuestión. Reconocer al prójimo es decisivo para los rumbos que se quieren imprimir a la propia vida.

Este primer encuentro marca toda la vida, es como una célula embrionaria, o como un foco qúe ilumina, por lo menos buena parte del camino. Su constante conquista es fundamental, para que felizmente sea generador de luz e ilumine de una vez toda la existencia del vocacionado, la conciencia de su significado y del alcance de esta luz es un descubrimiento que se hará a lo largo de toda la existencia. Es un proceso en el cual el rostro de Dios se va tornando cada vez más nítido hasta el encuentro definitivo.

El testimonio de una religiosa anciana de mi Congregación puede ayudar como ilustración de lo que acabo de afirmar. Yo era una joven religiosa y fui destinada a una comunidad numerosa. Éramos 21 hermanas. Entre éstas, dos mayores. Había entre nosotras un compromiso tácito de atención a ellas. Un día encontré a una de ellas desmayada en la alameda de la escuela, sola. La tomé en mis brazos para atenderla dentro de casa. Mientras se recuperaba, me miró a los ojos y me dijo: Hermana mía, es usted aún tan joven y entiende poco de la vida. Un día todo se le presentará más claro. Hizo una rápida síntesis de su vida y concluyó: Trabajé mucho; sufrí un poco; vine a la misión en Brasil y nunca más volví a Italia. Perdí los lazos con los familiares y con las Hermanas de allá. Y con una sonrisa que mis ojos conservan hasta hoy, dijo: Pero Dios, que es pura bondad, hizo bien todas las cosas en mi vida. Acertó en todo!

A partir de este encuentro, leo de otro modo, con otro corazón el texto bíblico de la historia de Abraham ya anciano y que, al recordar las bendiciones que había recibido de Dios, llama al siervo y le encarga buscar una esposa para Isaac, su hijo. La vida debe continuar porque tiene sentido, el sentido de la bendición de Dios. 


\section{Nueva "traditio" - La experiencia con Jesús de Nazaret}

Los relatos vocacionales de la Biblia, tanto en la antigua como en la nueva alianza, son bien conocidos. Todos ellos destacan la experiencia del encuentro personal con Dios, como Alguien, una Persona. El modo como sucede esto varía. La constante es siempre la experiencia relacional, de lo sagrado, del Otro. Lo diferencial es la prontitud de la persona en percibir lo que está aconteciendo en su vida y su decisión de servir. Esta espiritualidad de servicio, de Siervo, vivida por los profetas y profetisas, por María y Jesús es una espiritualidad que dice mucho también hoy a los jóvenes que sienten la irrupción sorprendente del Dios-sorpresa en sus vidas.

Aquí quiero atenerme sólo a la semana inaugural del ministerio público de Jesús, según la comunidad joanina. Se trata del tercero, cuarto y quinto días (Jn 1,35-51). Es el relato de la llamada de los primeros discípulos. Me llama la atención la exigencia de los éxodos y de las "pascuas", aliadas siempre necesarias. Los discípulos de Juan, tras el encuentro con el Maestro, el Cordero de Dios, pasan del discipulado de Juan al discipulado de Jesús. Simón es presentado a Jesús que lo mira a los ojos y cambia su nombre... su identidad. Felipe es encontrado por Jesús en el camino a Galilea e invitado a seguirlo. Felipe toma el camino del seguimiento de Jesús. Comparte su experiencia con Natanael. Natanael debe cambiar sus referencias a Moisés, a la Ley y los Profetas y relativizar la importancia dada al patriarca Jacob para participar de la comunidad de los que aceptan a Jesús, como el Mesías esperado y enviado por Dios.

El sello de identidad del llamado está muy claro: aquellos que aceptan la invitación de Jesús a seguirlo se convierten en medios de encuentro con Jesús para los demás. Es el celo por la gloria de Dios, por Su Reino. Esta pedagogía de introducción de otros en el misterio de Dios; este modo de escuchar, de aprender a pensar, a sentir y conocer recibió el nombre de mistagogia. Hoy la palabra mistagogia suena, en general, como anacrónica. Mientras, en una sociedad secularista como la nuestra, la primera misión de los que han encontrado al Señor es justamente la de proporcionar las condiciones necesarias para que otros también puedan hacer la experiencia de encuentro con Jesús. Esta "traditio" de fe, fruto de la experiencia del misterio de Dios, logrado en la contemplación, es hoy extremadamente necesaria. Es actuar como la Samaritana, después del encuen- 
tro en el pozo de Jacób: ¡Venid y ved! Salir de donde se está, desacomodarse y decidirse a ver! Es un ver interior, el ver de la fe, de certeza de lo que no se ve. Aprender a ver, a contemplar la belleza de Dios.

En primer lugar, es preciso despertar la fe recibida como don en el Bautismo. Es abrir caminos para la "traditio" de los principios evangélicos que nuestra sociedad, marcada por la indiferencia religiosa, dejó de lado. Tal como la comunidad joanina, también nosotros, hoy, precisamos ser sensibles y atentos/as para que la iniciación al misterio de Dios pueda transformarse en experiencia de vida para muchas personas.

En esta "traditio" y en esta mistagogia merecen puesto especial las imágenes de Dios que recibimos y hemos ido pasando como legado para los demás a lo largo de siglos, como si fuesen dogmas de fe. Algunas de esas imágenes contribuyen a tornar a Dios odioso a los ojos de tantas personas. Dios no es la imagen que de él hacemos. Él no es el todopoderoso, como afirmamos, Dios es todopoderoso solamente en el Amor. La fijación en una imagen de Dios corre el riesgo de idolatría. La Biblia nos llama la atención sobre este peligro de adorar imágenes. Y prohíbe toda imagen de Dios. Con todo la imagen nos es necesaria como vehículo de aproximación al misterio que siempre nos sobrepasa. En la "traditio" de la fe ayudamos a nuestros hermanos y hermanas a que recorran el camino de maduración en la fe, purificando a los pocos, pero siempre a imagen de Dios. Este cuidado en la educación de la fe y misión de la Iglesia.

\section{Nuevos Métodos}

El Papa Juan Pablo II no se cansa de animarnos a buscar "nuevos métodos, nuevas expresiones" y, fundamentalmente, "nuevo ardor misionero".

Toda simiente vocacional tiene el ADN de la misionariedad. Este es un síntoma de autenticidad de la llamada. Todos/as estamos llamados al servicio unos de los otros. También aquí vamos contracorriente de la sociedad circundante cada vez marcada por el individualismo.

Con Paulo VI, también nosotros invocamos a Maria, Madre y educadora de Jesús, la "Estrella de la Evangelización" a fin de que nos ayude a discernir y asumir con coraje y ardor los nuevos desafíos de la evangelización. 
El contacto con la persona de Jesús en los Evangelios es un camino de luz en la vida de los que aceptan la fe. Este indroducir en la fe, este proporcionar ocasiones de encuentro con la Persona de Jesús conforme los evangelios nos lo presentan, es hoy una urgencia, por causa del sincretismo religioso y la casi total ausencia de formación cristiana en las familias, ellas mismas tan brutalmente violentadas. Al final, más allá de la Biblia, poca cosa será realmente de gran utilidad para las personas de hoy. Es ante la Palabra, el Verbo Encarnado, Jesús de Nazaret, donde la persona va creando condiciones interiores para percibir las llamadas de Dios. Por eso tenemos que comenzar de nuevo. Y comenzar a partir de la genuina propuesta de Jesús de Nazaret. Y todo debe comenzar de nuevo, buscando en la única NOVEDAD que jamás la história registró: Jesús de Nazaret.

\section{Nuevos areópagos}

La mayoría de la población brasileña es urbana. En Brasil, más del $73 \%$. Esta no es una connotación cuantitativa o técnica, es una realidad cualitativa. En la ciudad se decide el futuro del país. Las urbes reúnen tecnología, personal, medios, condiciones capaces de crear, imponer, desarrollar, divulgar y mantener un sistema de vida con la ideología y las estructuras correspondientes.

No se trata sólo de aglomerados urbanos que están creciendo, sino de una nueva realidad irradiante, una nueva cultura, un nuevo modo de vivir, una afirmación de nuevos valores individuales y colectivos. Y por qué no decir que se trata de una nueva convocatoria a lanzarse más allá de lo conocido, descubrir sendas nuevas aún no pisadas, resignificando, con audacia, la misma fuerza de la fe. Siempre caemos en la tentación de la ideologia de las "buenas famílias rurales" donde aun hoy se piensa muchas veces que continúan siendo los únicos lugares verdaderamente teológicos, forjadores de vocaciones. Para la ciudad, vocaciones "ciudadanas"! 


\section{Conclusión}

Hay una canción que me gusta mucho y que dice más o menos así:

"En el rostro de la juventud, sonrisa y virtud, virando canción."

Rostro, juventud, sonrisa, canción... todas dimensiones ligadas al tema sobre el cual estamos hablando. Juventud, signo del Reino, hecho de justicia, paz alegría.

Rostro es identidad. Buscar "tener rostro" es tal vez el mayor desafío del trabajo vocacional. Tener rostro es tener propuesta, convicción. Sin rostro, no hay visión, no hay escucha, no hay palabra, no hay alimento. Tener rostro es tener identidad. El rostro es manera de ser.

Juventud es tiempo de llamada. Yo te llamé cuando aún eras joven. Te cogí de la mano y te conduje. Juventud, tiempo de busca y de compromiso, de estudio y de preparación, de descubrir descubriéndose en relación con Dios, con los otros y con el propio ser y existir.

Sonrisa es actitud de vida. Revela profundidad y claridad. Es expresión de madurez humana.

Virtudes son las cualidades necesarias para ordenar nuestros destinos.

Canción es el momento de lo lúdico y de lo profundo. Es meditación, silencio y contemplación que toca y eleva el alma, por eso es relación, con el Dios del arte, creador estético del ser y del vivir.

En la alegría del compromiso con Dios, con el Reino de Dios, con la lucha del pueblo, con la história-de todos los pueblos... en la consagración religiosa en busca de felicidad, con la juventud. 